\title{
KOMPARASI KOSTUM DAN TATA RIAS \\ DALAM MEMBANGUN 3 DIMENSI TOKOH - TOKOH PADA FILM “CINDERELLA" VERSI LIVE ACTION TAHUN 2015 DENGAN FILM VERSI ANIMASI TAHUN 1950
}

\author{
Elzha Noer Oktaviani \\ Nanang Rakhmad Hidayat \\ Agnes Widyasmoro \\ Jurusan Film \& Televisi, Fakultas Seni Media Rekam, Institut Seni Indonesia Yogyakarta \\ Jl. Parangtritis km. 6.5 Yogyakarta Telp. (0274) 381047
}

\begin{abstract}
ABSTRAK
Kostum dan tata rias menjadi alat komunikasi terhadap kepribadian tokoh pada film melalui peradaban kehidupan dan budaya manusia untuk memberikan ciri khas pada masingmasing tokoh. Keberadaan kostum dan tata rias dalam membangun 3 dimensi tokoh pada industri perfilman melalui genre bertajuk film fantasi menggunakan fenomena kultural sebagai inspirasi dalam menghasilkan prestasi dan apresiasi di tingkat Internasional. Salah satu keberhasilan tersebut terlihat pada Film "Cinderella" versi live action tahun 2015 yang diproduksi oleh Walt Disney. Film "Cinderella" versi live action tahun 2015 merupakan hasil remake film versi animasi pada tahun 1950 yang sama-sama diproduksi oleh Walt Disney, sebagai film adaptasi dari dongeng "Cinderella" karya penulis terkenal dari Perancis bernama Charles Perrault. Film "Cinderella" versi live action tahun 2015 dengan film versi animasi tahun 1950 mampu memberikan gambaran secara umum terhadap setting (waktu dan tempat) sebagai dunia imajinasi dan rekaan terinspirasi melalui tren gaya masyarakat Eropa.

Penelitian ini merupakan penelitian komparatif menggunakan metode kualitatif dengan pemaparan secara deskriptif. Analisis data kostum meliputi gaya dari bagian-bagian kostum disesuaikan dengan pakaian dasar, pakaian tubuh, asesoris, pakaian kepala, pakaian kaki, warna kostum untuk melihat tiga dimensi tokoh setiap karakternya dan tata rias sebagai pendukung dari gambaran masing-masing tokoh. Penelitian ini bertujuan untuk melihat persamaan dan perbedaan yang terjadi pada dua objek, ditinjau melalui implemetasi gaya dan warna kostum, serta jenis tata rias yang digunakan dalam membangun 3 dimensi pada tokoh "Cinderella", Ibu Tiri, Anastasia, Drizella, Pangeran.

Alasan terjadinya persamaan terinspirasi dari peristiwa sejarah masyarakat Eropa dengan melakukan mix up pada gaya kostum melalui dekorasi ornamen serta asesoris yang digunakan untuk mendukung masing- masing tokoh sesuai dengan kebutuhan tokohnya. Perbedaan terletak pada media yang berbeda terjadi pada tampilan kostum dan tata rias film versi animasi "Cinderella" tahun 1950 dalam bentuk animasi 2D, sedangkan film "Cinderella" tahun 2015 dalam bentuk live action.
\end{abstract}

kata kunci: kostum dan tata rias, 3 dimensi tokoh, film “cinderella" 2015 dengan film versi animasi tahun 1950

\section{Pendahuluan}

Film merupakan karya seni visual berdasarkan pada pengalaman hidup atau hasil imajinasi menjadi dunia rekaan. Film menjadi tontonan berkelas berkat tuntutan dari kaum borjuis melalui cerita dari kisahkisah kompleks, namun tetap menghibur, mengenai persolan-persoalan psikologis atau internal karakter (Panji Wibowo, 2017:26). Berbagai industri perfilman terbesar dalam menghasilkan banyak penghargaan dan apresiasi salah satunya adalah Hollywood. Hollywood merupakan sebuah nama daerah sekaligus nama jalan di Los Angeles, California, Amerika Serikat. Hollywood menjadi tempat sejarah perfilman sebagai 
industri film terbesar di dunia sejak awal dijadikan sebagai titik tolak perkembangan genre-genre besar dan berpengaruh hingga jumlah genre-genre telah mencapai puluhan (Pratista 2008, 12). Genre-genre terkenal dan berkembang di Hollywood meliputi aksi, drama, fantasi, horor, komedi, musikal, petualangan, perang, western, dan lain sebagainya. Industri perfilman Hollywood ternama dan terkenal di dunia melalui genregenrenya meliputi DreamWorks Picture, Colombia Picture, Metro Goldwyn Mayer, Paramount Picture, Warner Bros, Pixar, Castle Rock Entertaiment, Lionsgate, Scott Free, dan Walt Disney.

Hollywood bukan sekedar lokasi, hampir sepanjang sejarah estetika diciptakan menjadi ideologi sinema dominan di dunia. Formula Hollywood Klasik masih terus bertahan sampai sekarang antara lain dengan tokoh protagonis- antagonis, naratif sebabakibat, hubungan kasualitas dengan logika ketat dan universal, penutup dengan penyelesaian masalah atau keberhasilan protagonis mewujudkan keinginannya (Panji Wibowo, 2017:27). Walt Disney sebagai salah satu industri perfilman Hollywood menghasilkan film-film dengan karakteristik Hollywood Klasik. Walt Disney sebagai industri perfilman terkenal di dunia banyak mendapatkan prestasi dan penghargaan melalui karya film-filmnya dari masa ke masa melalui film animasi klasik hingga menjadi film live action. Film versi animasi
“Cinderella" karya dongeng Charles Perrault produksi Walt Disney pada tahun 1950 salah satu film animasi Hollywood menjadi film klasik dan legendaris terkenal di dunia.

Film versi animasi "Cinderella" sudah menjadi film kegemaran bertahun- tahun lamanya dan ditambah versi lain sejak dirilis oleh Walt Disney. Film versi animasi "Cinderella" tahun 1950 merupakan film versi animasi 2D adaptasi dari dongeng terkenal di dunia karya penulis asal Perancis bernama Charles Perrault.

Film versi animasi “Cinderella" bercerita tentang seorang gadis muda ditinggal oleh ayahnya karena meninggal dunia. Cinderella selalu ditindas semenjak tinggal bersama Ibu Tiri dan kedua saudara tirinya dengan perlakuan tidak simpatik terhadap dirinya.

Seiring dengan berkembangnya zaman sisi kreatif para sineas pun semakin meningkat tiap tahunnya. Pada tahun 2015 Walt Disney melahirkan kembali untuk mengingatkan kepada penggemar dongeng "Cinderella" atau film versi animasi "Cinderella" tahun 1950 pada seluruh dunia melalui Film “Cinderella” versi live action bertajuk film fantasi pada tahun 2015. Film "Cinderella" versi live action tahun 2015 secara garis besar mengikuti alur yang sama dan tokoh- tokoh yang sama dengan film versi animasi tahun 1950. Film versi live action bertajuk fiksi fantasi "Cinderella" 
disutradarai oleh Kenneth Branagh mempunyai berbagai prestasi dan apresiasi di tingkat internasional berkat penulis asal Inggris, serta kostum desainernya berasal dari Inggris juga. Sandy Powell sebagai penata kostum dalam melahirkan kostum dengan balutan kain-kain indah untuk masing- masing tokoh pada film “Cinderella" versi live action tahun 2015 menambah prestasi dan apresiasi dengan mendapatkan nominasi dan penghargaan pada kostum busana buatannya tersebut di tingkat Internasional.

Kostum dan tata rias tidak bisa dilepaskan dari perkembangan sejarah kehidupan dan budaya manusia. Keberhasilan film "Cinderella" versi live action tahun 2015 dengan film versi animasi tahun 1950 dalam menggambarkan suasana tertentu bertujuan untuk mengetahui informasi waktu maupun tempat terlihat pada keberhasilan penataan kostum dan tata rias. Kostum atau busana bisa berkontribusi terhadap latar dan mencerminkan sugesti tokoh lebih spesifik, meliputi situasi sosial, citra diri, pemikiran, dan lain-lain, seperti kostum orang kaya bisa sangat berbeda apabila kostum dan tata rias yang dipakai orang miskin. Sebagai salah satu contoh melihat dan mengamati kesederhanaan Cinderella melalui kostum dan tata rias sehari-sehari seperti wanita miskin di Eropa pada abad ke 16 dan 17 bahwa tokoh Cinderella dari latar belakang sosial kurang mampu. Berbeda halnya jika mengamati kostum dan tata rias tokoh Ibu Tiri dan kedua saudara tirinya dengan balutan kemewahan dan glamour. Sedangkan Pangeran memiliki kemewahan hidup melihat kostum dan tata rias layaknya bangsawan kara raya.

Setiap pemeran tokoh dilihat melalui kostum dan tata rias berdasarkan 3 dimensi untuk mengetahui sifat/watak tokoh sesuai perannya masing-masing meliputi dimensi fisiologis, dimensi sosiologis, dan dimensi psikologis (Harymawan 1998, 25). Pada film "Cinderella" versi tahun 2015 dengan film versi animasi tahun 1950 mempunyai tokoh-tokoh dengan sifat/watak sama. Tokoh protagonis adalah Cinderella, tokoh antagonis Ibu tiri, Anatasia, Drizella, dan tokoh tirtagonis Pangeran. Kelima tokoh tersebut menjadi tokoh saling bertentangan dan sering muncul pada kedua film. Penelitian tentang kostum dan tata rias menjadi sangat penting karena keberadaanya bisa dilihat secara kasat mata merupakan bagian dari elemen artistik sebagai salah satu unsur dari empat mise-en-scene dalam menyempurnakan sebuah suasana waktu dan tempat berdasarkan dengan realitas cerita sesuai dengan masa atau eranya. Permasalah dalam penelitian ini, sebagai berikut: 


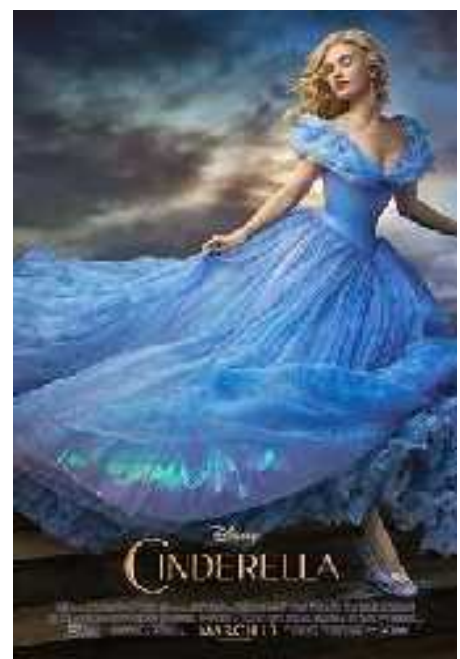

Gambar 1 Poster Film "Cinderella" Versi Live Action Tahun 2015 (Sumber: http://movies.disney.id/cinderella diakses 08/02/2017 20:14)

1. Bagaimana kostum dan tata rias pada film "Cinderella" versi live action tahun 2015 dengan film Cinderella versi animasi tahun 1950 ?

2. Apakah kostum dan tata rias membangun 3 dimensi tokoh-tokoh pada film "Cinderella" versi live action tahun 2015 dengan Film versi animasi tahun $1950 ?$

3. Apa persamaan dan perbedaan kostum dan tata rias dalam membangun 3 dimensi pada film "Cinderella" versi live action tahun 2015 dengan film versi animasi tahun 1950 ?

4. Mengapa terjadi persamaan dan perbedaan kostum dan tata rias dalam membangun 3 dimensi tokoh-tokoh pada kedua film tersebut?

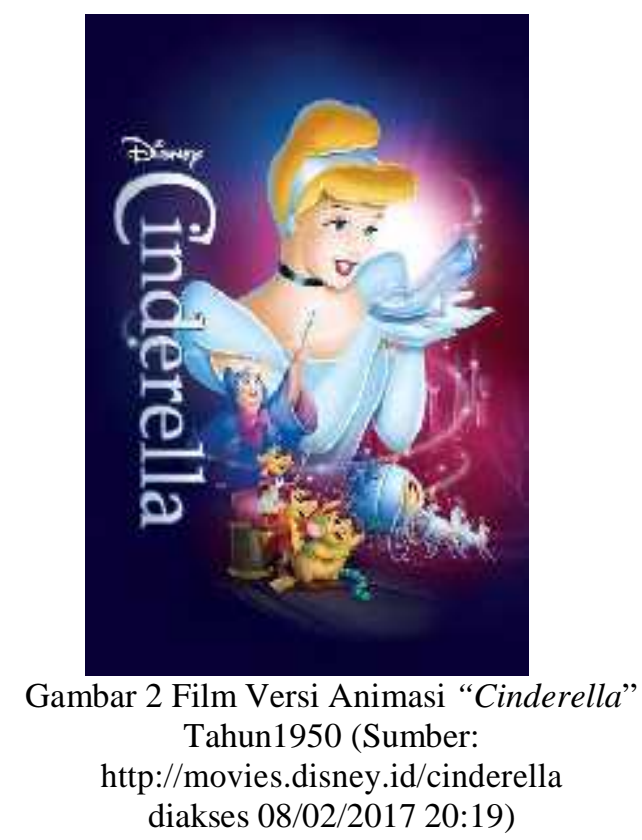

Penelitian dengan menggunakan metode kualitatif ini dimaksudkan untuk memberikan pemahaman pada fenomena subjek penelitian berupa penjelasan secara deskripsi terhadap suatu konteks khusus secara alamiah dan memanfaatkan berbagai metode alamiah melalui bentuk kata-kata dan bahasa (Moleong 2007, 6).

Penelitian deskriptif melakukan analisis hanya sampai pada taraf deskripsi, yaitu menganalisis dan menyajikan fakta secara sistematik sehingga dapat lebih mudah untuk difahami dan disimpulkan (Azwar 2001,6).

Penelitian komparatif menurut Aswarni sudjud dalam buku milik Suharsimi Arikunto berjudul Prosedur Penelitian merupakan penelitian komparasi akan dapat menemukan persamaan-persamaan dan perbedaanperbedaan tentang benda-benda, tentang orang, tentang prosedur kerja, tentang ideide, kritik terhadap orang, kelompok, terhadap suatu ide atau suatu prosedur kerja. Dapat juga membandingkan kesamaan 
pandangan dan perubahan-perubahan pandangan orang, gru atau negara, terhadap kasus, terhadap orang, peristiwa atau terhadap ide-ide. (Arikunto 2010, 310).

Film versi animasi tahun 1950 dengan total jumlah sampel sama adalah 10 jenis kostum dibagi pada tokoh Cinderella berjumlah 2 jenis kostum beserta tata riasnya, tokoh Ibu Tiri berjumlah 2 jenis kostum beserta tata rias, tokoh Drizella dan Anastasia masing-masing 2 jenis kostum beserta tata riasnya, serta tokoh pangeran 2 jenis kostum beserta tata riasnya. Proses pengambilan sampel secara teknik sample random sampling menghasilkan 20 jenis kostum beserta tata rias sebagai pendukungnya.

Pengambilan dua kostum dari kedua objek adalah kostum sehari-hari karena tokoh banyak melakukan aksinya pada aktivitas sehari-hari dengan kostum pesta yang mengalami banyak perubahan pada tokoh utama. Pengambilan teknik sampel random sampling karena populasi bersifat homogen dan sampel diambil secara random dengan mencari sampel yang representatif. Kedua kostum tersebut dipilih karena kedua kostum bersifat representatif untuk menunjukkan kepribadian 3 dimensi tokoh-tokoh pada kedua film. Sampel diambil perjenis kostum karena kostum pesta berbeda dengan kostum sehari-hari. Kostum sehari-hari tidak bias mewakilkan kostum pesta dan begitu pun sebaliknya, maka dipilihkan dua jenis kostum tersebut. Sampel bersifat representatif sama karena penelitian ini adalah penelitian perbandingan.

\section{Skema Penelitian}

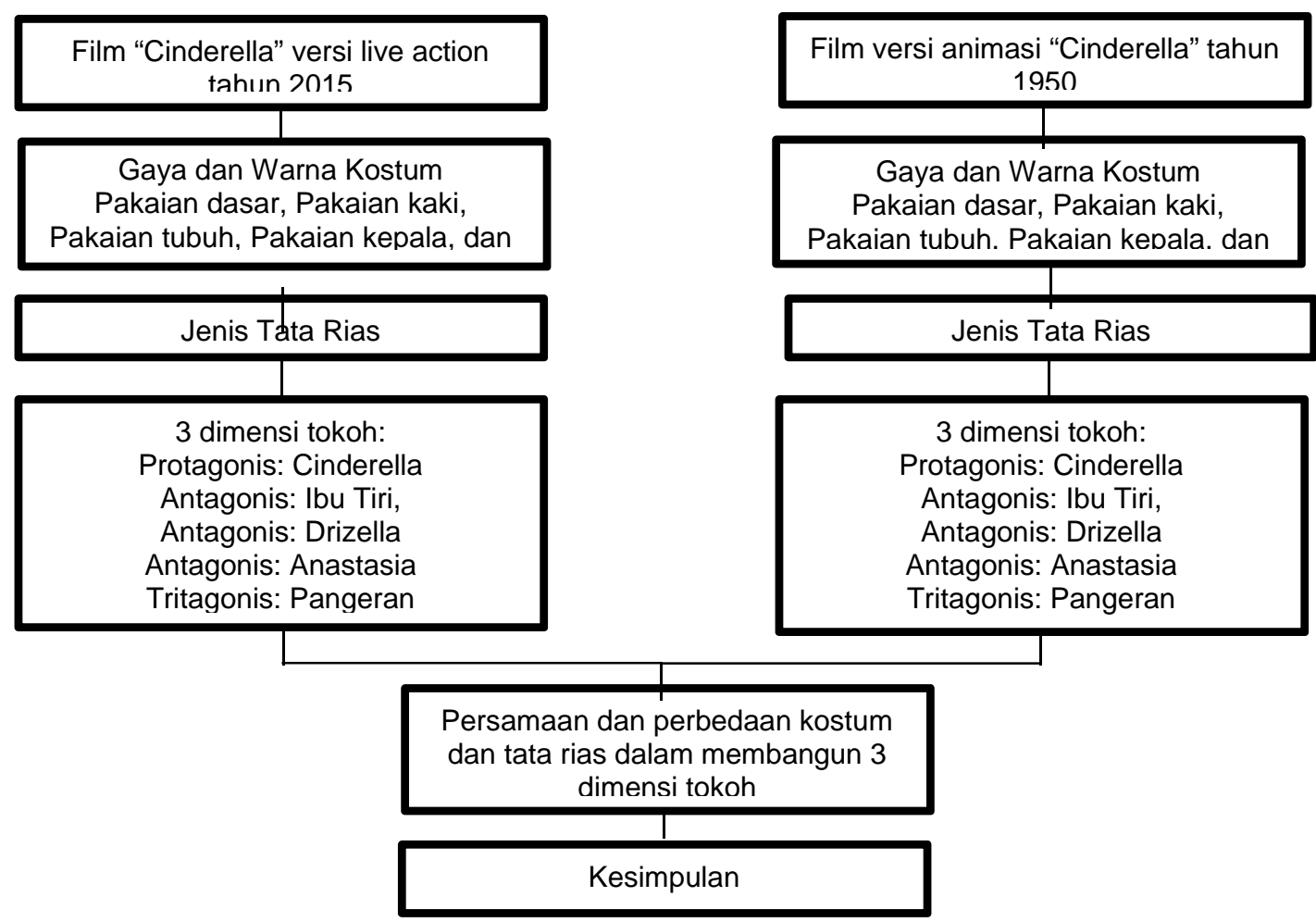




\section{Pembahasan}

Setelah melakukan proses penelitian melalui proses observasi dengan mengamati kedua objek penelitian pada film “Cinderella" versi live action tahun 2015 dengan film versi animasi tahun 1950 dan melakukan proses analisis untuk melihat persamaan dan perbedaan kostum dan tata rias dalam membangun 3 dimensi masingmasing tokoh pada kedua film. Hasil penelitian diperoleh data melalui proses pengambilan sampel dengan model teknik sample random sampling bertujuan untuk mengutamakan pengambilan sampel dengan pertimbangan keseimbangan dalam perbandingan dua objek penelitian. Pengambilan teknik sampel random sampling karena populasi bersifat homogen dan sampel diambil secara random dengan mencari sampel yang representatif.

Kostum sehari-hari dengan kostum pesta dansa tersebut dipilih karena kedua kostum bersifat representatif untuk menunjukkan kepribadian 3 dimensi tokohtokoh pada kedua film. Sampel diambil perjenis kostum karena kostum pesta berbeda dengan kostum sehari-hari. Kostum sehari-hari tidak bisa mewakilkan kostum pesta dan begitu pun sebaliknya, maka dipilihkan dua jenis kostum tersebut. Data diperoleh mengenai kostum dengan menggolongkannya pada 5 bagian meliputi pakaian dasar, pakaian tubuh, asesoris, pakaian kepala, dan pakaian kaki untuk melihat gaya, warna, serta jenis tata rias yang digunakan pada kedua film sesuai dengan setting (waktu dan tempat) cerita yang sama karena dalam kisah film "Cinderella" di Perancis dengan tampilan kostum lebih terinspirasi gaya atau era victorian saat pertama kali Ratu Victoria menjabat sebagai Ratu Inggris pada tahun 1837. Penerapannya dalam kostum dan tata rias pada tokoh Cinderella, Ibu Tiri, Anastasia, Drizella, dan Pangeran menyesuaikan setting waktu pada Era Victorian, dan periode-periode sebelumnya seperti periode renaissance dengan abadabad pencerahan dalam mengaplikasikan trend kostum pada masa itu. Perkembangan kostum di abad ke 18 dan abad 19 dan abadabad sebelumnya merupakan titik awal memulainya pilihan-pilihan kostum karena munculnya kostum dengan banyak variasivariasi untuk abad-abad selanjutnya.

Pada film “Cinderella" versi live action tahun 2015 terdapat banyaknya detail dekorasi ornamen dan asesoris yang digunakan untuk mendukung masingmasing tokoh sesuai dengan kebutuhannya. Sedangkan film versi animasi tahun 1950 dengan teknologi yang sangat sederhana tidak memungkinkan untuk membuat detail pada kostum. Berikut hasil penelitian pada tokoh Cinderella dan Pangeran sebagai perwakilan dalam penelitian ini:

1. Tokoh Ella versi live action dengan tokoh Cinderella versi animasi 
Pada tokoh Ella dan Cinderella melalui kostum sehari-hari banyak terinspirasi dengan digambarkan memakai kostum berupa gaya abad ke 16 dan 17 bergaya baroque atau menggambarkan wanita Skandinavia untuk menjadi tokoh wanita miskin atau kaum budak. Kostum Ella menggunakan tambahan dekorasi ornamen gaya rococo abad ke 18 . Gaun yang paling terkait dengan gaya Robe à la Française abad 18 adalah rococo (gaya dekoratif arsitektur, fashion, dan desain interior yang menampilkan desain murni hias dan orname bunga yang rumit, populer antara 1715 dan 1775) (Sara Pandergast dan Tom Pandergast, 2004:568). Sedangkan tokoh Cinderella versi animasi tidak terdapat detail kostum. Gaya pakaian wanita kalangan atas mengenakan gaun dengan gaya rococo terbuat dari terbuat dari kain yang kaya dan sarat dengan dekorasi berenda. Pada kostum pesta dansa, tokoh Ella dan Cinderella digambarkan sama-sama memakai kostum dengan gaya Victorian abad ke 19. Tampilan mode ini menghadirkan korset ketat, rok raksasa, dan membuat tren fashion pada periode tersebut. Gaya pakaian didikte dengan kesopanan, dan pakaian bergaya merupakan tanda kehormatan.

Warna pada dua kostum menggunakan warna biru, dan coklat menggambarkan tokoh yang memiliki kesedihan, kerendahan hati, berhati tulus, mudah berteman dan menyukai orang lain.

Tata rias yang digunakan oleh Ella menggunakan make up beauty dan korektif untuk mengkoreksi bagian alis mata, hidung, tulang pipi, dan bibir.

2. Pangeran versi live action dengan versi animasi

Kostum sehari-hari dan kostum pesta dansa Pangeran versi live action dengan Pangeran versi animasi sama-sama menggunakan gaya kostum victoria pada abad ke 19 dengan gaya terispirasi dari kostum Pangeran Albert pada masa pemerintahan Ratu Victoria di Inggris pada abad ke 19 sekitar tahun 1837-1901. Gaya kostum Pangeran versi live action sama dengan gaya Kaisar Napoleon Bonaparte seorang pemimpin militer dan politik Prancis yang menjadi terkenal saat Perang Revolusioner, setelah Revolusi Prancis pada abad ke 18 sekitar tahun 1789 .

Pengggunaan kostum sehari-hari dengan pesta dansa pada tokoh Pangeran versi live action terdapat frock-coat memiliki warna yang tidak terlalu mencolok. Kostum seperti yang dipakai Pangeran versi live action merupakan pakaian dengan istilah kamus menggunakan bahasa Prancis seperti jas dari katun dengan jabot atau dasi, ditutupi dengan rompi tanpa lengan disebut dengan justaucorps, jas atau frock dengan lengan panjanga atau mantel panjang, celana lutut yang disebut 
dengan breeches dipakai oleh pria Eropa sepanjang abad ke 18. Pada kostum seharihari dan pesta dansa Pangeran live action terdapat dekorasi ornamen flora pdengan gaya rococo abad ke 18 seperti dedauanan pada frock-coat serta di bagian rompi dalam yang dipakai Pangeran. Pangeran versi animasi tidak memiliki kostum sehari-hari, hanya menggunakan kostum pesta dansa dan kostum pernikahan dengan jenis yang sama. Pangeran versi animasi kostum seperti prajurit kerajaan terdapat belt, pada sisi kanan dan kiri kostum terdapat epaulets, serta aiguillete seperti rantai emas.

Keterkaitan warna kostum dengan karakter yang mudah bergaul, santai, tenang, teguh, sabar, seimbang, tidak banyak bicara tetapi cenderung bijaksana, simpatik, baik hati, berbelaskasihan, mudah diajak rukun dan damai. Sedangkan Pangeran animasi warna kostum pesta berwarna coklat dan merah yang mewakili karakter Pangeran yang berani, santai, tidak banyak bicara tetapi cenderung bijaksana, simpatik, baik hati, berbelaskasihan dan peduli.

Tata rias yang digunakan oleh Pangeran live action dengan animasi sama- sama menggunakan tata rias korektif untuk mengkoreksi bagian alis mata, hidung, tulang pipi, dan bibir.

\section{Dimensi tokoh}

Berdasarkan pada tahapan-tahapan analisa penelitian sesuai dengan 3 dimensi tokoh melalui dimensi fisiologis (ciri-ciri badani), tokoh dengan dimensi sosiologis (latar belakang masyarakat), dan tokoh dengan dimensi psikologis (latar belakang kejiwaan). Hasil analisis pada tokoh Cinderella, Ibu Tiri, Anastasia, Drizella, dan Pangeran secara menyeluruh sesuai dengan 3 dimensi tokoh pada penjelasan data di atas.

Kostum membangun sesuai dengan tokoh-tokoh kedua film pada tokoh Cinderella, Ibu Tiri, Anastasia, Drizella, dan Pangeran meliputi dimensi fisiologis dengan menggambarkan kondisi fisik tokoh seperti kesederhanaan, kemewahan, kecantikan, kegagahan, kerapihan, kewibawaan, dan daya tarik tokoh. Dimensi sosiologis menunjukan kelas sosial ekonomi, kehidupan keluarga, kewarganegaraan, dan hobi pada tokoh. Dimensi psikologis menggambarkan perasaan sesuai warna pada kostum meliputi kepribadian, tempramen, cara tokoh menyikapi kehidupan seperti, kebaikan, keberanian, ketulusan, emosi, dan visi masing-masing tokoh pada kedua film tersebut.

Berikut hasil penelitian pada tokoh Cinderella dan Pangeran sebagai perwakilan dalam penelitian ini:

1. Tokoh Ella versi live action dengan tokoh Cinderella versi animasi

Kostum sehari-hari dengan kostum pesta dansa tersebut menujukkan 3 dimensi tokoh secara fisiologis tampak sederhana tetapi masih memiliki kesan mewah. Secara sosiologis 
mencerminkan keturunan Inggris, seorang wanita miskin yang berubah menjadi wanita kaya. Secara dimensi psikologis ditaris garis warna biru dan coklat menggambarkan tokoh yang memiliki kesedihan, kerendahan hati, berhati tulus, mudah berteman dan menyukai orang lain.

Tokoh Ella versi live action dengan tokoh Cinderella versi animasi adalah tokohr yang sama-sama memiliki kepribadian ambivert dengan tempramen sanguinis. Keterkaitan warna kostum dalam membangun karater bahwa karakter warna biru dan coklat pada karakter Ella merupakan karakter yang sedih, berhati tulus, cerah, mudah berteman, menyukai orang lain. ekspresif, dan ceria.

2. Pangeran versi live action dengan versi animasi

Kostum pada tokoh Pangeran versi live action dan animasi secara fisiologis terlihat kegagahan, kerapihan, kewibawaan, dan daya tarik, Secara sosiologis keduanya keturunan Inggris menjadi pria bangsawan yang kaya raya. Secara dimensi psikologis ditarik garis warna muncul warna hijau, kuning kehijauan, putih, dan biru. Warna tersebut mewakili 3 dimensi tokoh Pangeran live action yang mudah bergaul, santai, tenang, teguh, sabar, seimbang, tidak banyak bicara tetapi cenderung bijaksana, simpatik, baik hati, berbelaskasihan, mudah diajak rukun dan damai. Sedangkan Pangeran animasi warna kostum pesta berwarna coklat dan merah yang mewakili 3 dimensi tokoh Pangeran yang berani, santai, tidak banyak bicara tetapi cenderung bijaksana, simpatik, baik hati, berbelaskasihan dan peduli. Persamaan 3 dimensi tokoh Pangeran versi live action dengan versi animasi memiliki tempramen plegmatis. Perbedaan yang terjadi pada Pangeran live action memiliki kepribadian ekstrovert yang cenderung membuka diri dengan kehidupan luar yang lebih beraktivitas dan lebih sedikit berpikir, serta orang yang senang berada di keramaian atau kondisi yang terdapat orang banyak, daripada di tempat yang sunyi. Tokoh Pangeran versi live action memiliki kekuatan temperamen plegmatis dengan kepribadian sangat dihormati karena dirinya mudah bergaul, santai, tenang, dan teguh. Pangeran Kit juga memiliki temperamen yang cerah dan hangat.

Sedangkan Pangeran versi animasi disimpulkan cenderung memiliki kepribadian introvert menutup diri dari kehidupan luar yang lebih senang berada di kesunyian atau kondisi tenang, daripada tempat yang banyak orangnya. 
Pangeran versi animasi yang tidak terlalu banyak diperlihatkan aktivitasnya pada film versi animasi memiliki kekuatan phlegma atau plegmatis (lendir). Cairan phlegma memiliki tipe kepribadian yang khas seperti tidak suka terburu-buru, tenang, tidak mudah dipengaruhi, setia, dingin, santai dan sabar.

\section{Persamaan dan perbedaan}

Berdasarkan masing-masing pengamatan, dilakukan perbandingan atau komparasi telah melalui proses analisis secara deskriptif dapat dilihat bahwa persamaan kostum sesuai dengan setting (waktu dan tempat) dan perbedaan keduanya tampilan kostum karena sifat media yang berbeda sehingga film versi animasi dibuat sangat sederhana dengan memiliki tingkat kesulitan yang tinggi untuk menampilkan detail pada kostum.

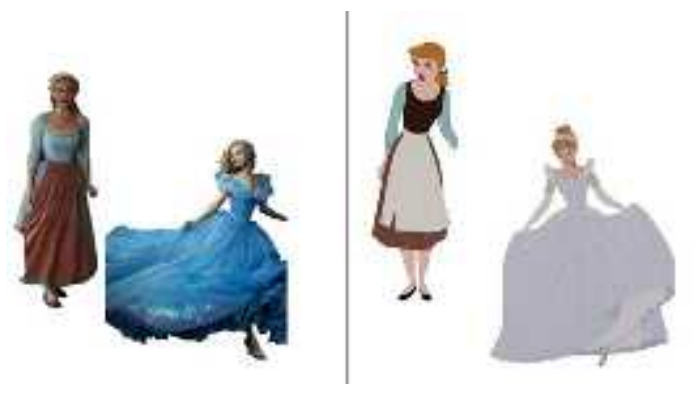

Gambar 3 Perbandingan kostum dan tata rias tokoh Cinderella
Pada film live action secara produksi lebih mudah dalam menampilkan detail kostum, maka tampilan kostum pada tahun 2015 dibuat sangat detail untuk melengkapi kebutuhan masing-masing tokohnya.

Tabel di bawah ini akan menjabarkan persamaan dan perbedaan kostum dan tata rias dalam membangun 3 dimensi tokohtokoh pada film "Cinderella" versi live action dengan film versi animasi tahun 1950. Tabel di bawah ini hanya akan menyajikan detail kostum dan tata rias dalam membangun 3 dimensi tokoh pada tokoh Cinderella dengan Pangeran sebagai perwakilan perbandingan untuk melihat persamaan dan perbedaannya sebagai berikut:

\section{Tokoh Ella versi live action dengan}

\section{Cinderella versi animasi tahun 1950}

Di bawah ini untuk mengetahui persamaan dan perbedaan kostum dan tata rias sehari-hari dan pesta dansa pada tokoh Ella versi live action tahun 2015 dengan tokoh Cinderella versi animasi tahun 1950.

Tabel di bawah ini akan menyajikan detail persamaan dan perbedaan kostum dan tata rias sehari-hari dan pesta dansa pada tokoh Ella versi live action tahun 2015 dengan tokoh Cinderella versi animasi tahun 1950 sebagai berikut: 
Tabel 1 Perbandingan kostum dan tata rias tokoh Cinderella

\begin{tabular}{llll}
\hline \multicolumn{1}{c}{ Keterangan } & \multicolumn{2}{c}{ Persamaan } & \multicolumn{2}{c}{ Perbedaan } \\
\hline Kostum & Pada bagian kostum gaya yang digunakan & Pada kostum Ella terdapat dekorasi ornamen \\
sehari-hari & Ella versi live action dengan Cinderella versi & dengan gaya rococo abad ke 18. Gaya rococo \\
& tahun 1950 menggunakan gaya berlatar & sebuah dekorasi ornamen bunga-bunga pada bagian \\
& belakang Perancis sehingga muncul gaya & bawah rok lingkar penuh pada dress yang \\
& kostum dengan terinspirasi pada abad ke 16 & digunakan Ella. Sedangkan dress yang digunakan \\
& dan 17. Persamaan gaya pada abad ke 16 dan & Cinderella tidak menggunakan ornamen apapun. \\
& 17 menggambarkan gaya baroque dan & Dress dengan kain polos melingkar pada tubuh \\
& menggambarkan wanita miskin Skandinavia & Cinderella. Pada dress warna paling dominan \\
& terlihat pada pkaian dasar, pakaian tubuh, adalah warna coklat, walaupun terdapat warna biru \\
& asesoris, pakaian kepala hingga pakaian pada lengan.
\end{tabular}
kakinya. Pada bagian warna kostum Ella lebih mendominasi warna biru, walaupun pada ornamen terdapat warna coklat.

Kostum pesta Pada kostum pesta dansa Ella dan juga dansa Cinderella mengguakan ball gown dengan gaya Victorian pada abad ke 19 sekitar tahun 1837-1901 melihat kduanya memiliki siluet yang sama dengan menggunakan crinoline pada bagian lingkaan pinggang sebagai kerangka. Pada pakaian tubuh dan pakian kaki memiliki siluet yang sama. Pemilihan warna pada kostum Ella dan Cinderella sama-sama menggunakan warna biru, tetapi warna biru pada kostum Ella lebih kuat seperti warna biru yang tidak biasanya dengan mencampur warna-warna lain agar terlihat seperti watercolour.

Tata rias Ella dan Cinderella menggunakan tata rias sehari-hari dengan jenis yang sama yakni tata ria korektif untuk menampilkan kesederhanaan pada penampilan tokoh.

Tata rias Tata rias yang digunakan oleh Ella dan juga pesta dansa Cinderella samasama menggunakan make up beauty dan korektif untuk mengkoreksi bagian alis mata, hidung, tulang pipi, dan bibir.

3 dimensi Ella dan Cinderella memiliki sifat yang tokoh sama-sama ambivert dengan temperamen sanguinis. Keterkaitan warna kostum dalam membangun karater bahwa karakter warna biru pada tokoh Ella merupakan sifat yang sedih, berhati tulus, cerah, ekspresif, dan ceria
Pada kostum Ella terdapat dekorasi kupu-kupu pada kerah decollete karena desainer menghubungkannya dengan karakter Ella yang menyatu dengan alam dan senang berteman dengan binatang- binatang. Dekorasi tersebut memilih kupu-kupu karena kupu-kupu adalah binatang yang indah. Sedangkan pada kostum Cinderella tidak menggunakan dekorasi apapun.

Pada kostum pesta dansa versi live acion dalam merealisasikan kilauan cahaya pada kostum animasi dengan menghadirkan 4000 LED kecilkecil yang dipasangkan pada kostum Ella dan menambahkan 10.000 kristal yang menambah efek berkilauan.

Warna pada kostum Cinderella biru yang pudar sehingga kostum tidak cerah seperti kostum Ella versi live action. Pada penggunaan asesoris Ella terlihat lebih sederhana dibandingkan Cinderella yang terdapat Pita pada lingkaran leher, dan sarung tangan yang menutupin bagian tangan hingga lengannya. Pada bagian pakaian kepala Ella dengan model rambur curly blonde hairstyle yang indah terurai sedangkan Cinderella dengan model rambut dengan sanggulan gaya franch twist hair.

Perbedaan terletak pada bagian warna bibir. Ella menggunakan warna merah bata sebagai warna natural sedangkan Cinderella menggunakan warna pink sebagai warna naturalnya.

Tata rias Ella juga terlihat menggunakan make up beauty untuk merealisasikan make up agak lebih ditonjolkan dan menggunakan warna perona bibir merah bata. Sedangkan Cinderella masih menggunakan tata rias yang natural dengan pernoa bibir masih menggunakan warna pink.

Ella cenderung terkait dengan warna

biru dan coklat yang mendominasi memiliki watak warna pada tokoh yang memiliki kesedihan, kerendahan hati, berhati tulus, mudah berteman dan menyukai orang lain. Pada tokoh Cinderella pada versi animasi memang Cinderella paling mendominasi adalah persahabatannya dengan teman-teman binatangnya yang selalu menolong dalam keadaan apapun. 
2. Tokoh Pangeran versi live action

\section{dengan animasi versi tahun 1950}
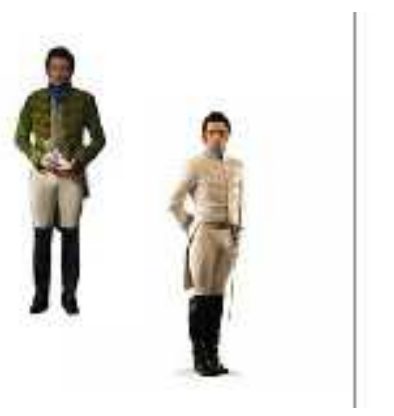

Gambar 4.140 Perbandingan kostum dan tata rias tokoh Pangeran
Di bawah ini untuk mengetahui persamaan dan perbedaan kostum dan tata rias sehari-hari dan pesta dansa pada tokoh Pangeran versi live action tahun 2015 dengan tokoh Pangeran versi animasi tahun 1950 .

Tabel di bawah ini akan menyajikan detail persamaan dan perbedaan kostum dan tata rias sehari-hari dan pesta dansa pada tokoh Pangeran versi live action tahun 2015 dengan tokoh Pangeran versi animasi tahun 1950 sebagai berikut:

Tabel 4.35 Perbandingan kostum dan tata rias tokoh Pangeran

\begin{tabular}{|c|c|c|}
\hline Keterangan & Persamaan & Perbedaan \\
\hline $\begin{array}{l}\text { Kostum } \\
\text { sehari-hari } \\
\text { dan pesta } \\
\text { dansa }\end{array}$ & $\begin{array}{l}\text { Persamaan kostum sehari- } \\
\text { hari dan kostum pesta } \\
\text { dansa Pangeran versi live } \\
\text { action dengan Pangeran } \\
\text { versi animasi sama-sama } \\
\text { menggunakan gaya kostum } \\
\text { victoria pada abad ke } 19 . \\
\text { Pakaian kepala Pangeran } \\
\text { versi live action dengan } \\
\text { Pangeran versi animasi } \\
\text { sama-sama bergaya } \\
\text { victorian pada model } \\
\text { rambut lakilaki abad ke } 19 .\end{array}$ & $\begin{array}{l}\text { Perbedaan terletak pada Pangeran versi animasi tidak memiliki } \\
\text { kostum seharihari, hanya menggunakan kostum pesta dansa dan } \\
\text { kostum pernikahan dengan jenis yang sama. Pada kostum sehari-hari } \\
\text { dan pesta dansa Pangeran versi live action terdapat dekorasi ornamen } \\
\text { flora seperti dedauanan pada frock-coat serta di bagian rompi dalam } \\
\text { yang dipakai Pangeran. sedangkan Pangeran versi animasi kostum } \\
\text { seperti prajurit kerajaan terdapat belt, pada sisi kanan dan kiri kostum } \\
\text { terdapat epaulets, serta aiguillete seperti rantai emas. Pangeran versi } \\
\text { live action pada kostum sehari-hari dan pesta dansa menggunakan } \\
\text { breeches atau celana panjang berketat, sedangkan Pangeran animasi } \\
\text { menggeser keberadaan breeches dengan celana panjang yang biasa } \\
\text { digunakan oleh Prajurit Kerajaan Inggris. Perbedaan lainnya adalah } \\
\text { Pakaian sepatu sehari-hari dan pesta dansa Pangeran versi live action } \\
\text { menggunakan jookey boots, sedangkan Pangeran versi animasi hanya } \\
\text { menggunakan sepatu army boots. Pemilihan warna kostum sehari } \\
\text { Pangeran versi live action menggunakan warna hijau, kuning } \\
\text { kehijauan, putih, biru, sedangkan kostum pesta dansa berwarna putih } \\
\text { dan biru. Sedangkan pemilihan warna kostum pesta dansa berwarna } \\
\text { coklat dan merah. }\end{array}$ \\
\hline $\begin{array}{l}\text { Tata Rias } \\
\text { sehari hari } \\
\text { dan pesta } \\
\text { dansa }\end{array}$ & $\begin{array}{l}\text { Tata rias yang digunakan } \\
\text { oleh Pangeran versi live } \\
\text { action dengan versi } \\
\text { animasi sama-sama } \\
\text { menggunakan tata rias } \\
\text { korektif untuk } \\
\text { mengkoreksi bagian alis } \\
\text { mata, hidung, tulang pipi, } \\
\text { dan bibir. }\end{array}$ & Tidak terdapat perbedaan pada tata rias kedua tokoh. \\
\hline $\begin{array}{l}3 \text { dimensi } \\
\text { tokoh }\end{array}$ & $\begin{array}{l}\text { Persamaan watak Pangeran } \\
\text { versi live action dengan } \\
\text { versi animasi memiliki } \\
\text { temperamen plegmatis. }\end{array}$ & $\begin{array}{l}\text { Perbedaan yang terjadi pada tokoh Pangeran versi live action adalah } \\
\text { tokoh yang ekstrovert dengan kata lain Pangeran ini menyukai hal- } \\
\text { hal yang melibatkan orang lain, dan membuka dirinya dengan mudah } \\
\text { bercerita kepada orang lain, sedangkan Pangeran versi animasi } \\
\text { cenderung introvert karena keberadaan Pangeran tidak banyak } \\
\text { dilakukan seperti halnya Pangeran hanya dimunculkan saat pesta } \\
\text { dansa dan pernikahan. Pangeran versi animasi juga sangat tertutup } \\
\text { ketika berada di pesta dansa. Pangeran senang dengan suasana tenang } \\
\text { terutama pada pesta dansa, Pangeran hanya berinteraksi dengan }\end{array}$ \\
\hline
\end{tabular}


Cinderella saja. Keterkaitan warna kostum sehari-hari dengan kostum pesta dansa ditarik garis warna dari kedua kostum akan muncul warna hijau, kuning kehijauan, putih, dan biru. Warna tersebut mewakili watak Pangeran versi live action dengan karakter yang mudah bergaul, santai, tenang, teguh, sabar, seimbang, tidak banyak bicara tetapi cenderung bijaksana, simpatik, baik hati, berbelaskasihan, mudah diajak rukun dan damai. Sedangkan Pangeran versi animasi warna kostum pesta berwarna coklat dan merah yang mewakili karakter Pangeran yang berani, santai, tidak banyak bicara tetapi cenderung bijaksana, simpatik, baik hati, berbelaskasihan dan peduli.

\section{Alasan persamaan dan perbedaan}

Pada penjelasan di atas bahwa secara deskriptif terkait persamaan dan perbedaan kostum dan tata rias sesuai dengan 3 dimensi tokoh-tokoh pada film "Cinderella" versi tahun 2015 dengan film versi animasi tahun 1950. Hal tersebut dilihat pada tokoh Cinderella menggunakan kostum dan tata rias dengan tingkatan sosial menengah ke bawah, Ibu Tiri, Anastasia, Drizella tingkatan sosial menengah ke atas, dan Pangeran kalangan bangsawan.

Berdasarkan dengan data yang telah diperoleh bahwa alasan terjadinya persamaan dan perbedaan sebagai berikut:

\section{Setting (waktu dan tempat)}

Alasan terjadinya persamaan pada data di atas bahwa kostum yang digunakan masing-masing tokoh disebabkan setting (waktu dan tempat) pada film "Cinderella". Kedua film secara keseluruhan menggunakan setting tempat di Perancis pada abad ke 19 sekitar tahun 1937 pada masa Ratu Victoria menjabat di Inggris dengan menggunakan gaya Victorian seperti pada kostum Cinderella, Ibu Tiri, Anastasia, Drizella, dan Pangeran.
Kostum juga tidak hanya menggunakan abad ke 19 dengan melakukan mix up dari periode-periode sebelumnya.

\section{Media}

Perbedaan terletak pada sifat medianya yang digunakan. Pada tahun 2015 film "Cinderella" dalam kurun waktu yang cukup lama dari pembuatan awal film versi animasi pada tahun 1950, Walt Disney mengubahnya menjadi film bertajuk fiksi fantasi dalam bentuk versi live action. Film bertajuk dunia fantasi atau dunia imajinasi dengan tokoh film yang nyata diperankan oleh manusia dalam bentuk film live action. Pada film versi live action ini memungkinkan seorang perancang busana dalam merealisasikan desain kostum dengan sangat detail. Pada film "Cinderella" versi live action tahun 2015 juga menggunakan salah satu teknologi digital yang canggih dan moderen digunakan untuk membuat film live action terlihat lebih fantastis dalam produksi sebuah film layar lebar adalah menggunakan teknologi CGI atau Computer Generated Imagery. Sandy Powell sebagai perancang busana 
juga mengakui bahwa dirinya bekerjasama dan menemani petugas yang bertanggung jawab pada visual efek.

CGI adalah teknik penerapan teknologi komputer grafis 3D untuk pembuatan spesial efek. Selain dengan teknologi CGI, pembuat film juga menggunakan layar berwarna hijau atau dikenal dengan green screen. Penggunaan utama layar hijau ditujukan lebih menonjolkan objek utama sekaligus melakukan blocking terhadap latar belakang sehingga mudah untuk diedit atau dihilangkan untuk diganti dengan gambar lain. Pemanfaatan teknologi tersebut hasil film yang dibuat telihat seperti nyata .

Film versi animasi“Cinderella” pada tahun 1950 merupakan film traditional animation atau animasi 2D digunakan pada saat animasi pertama kali dikembangkan. Pembuatan film versi animasi“ "Cinderella” menggunakan teknik cel animation karena tehnik pengerjaannya dilakukan pada celluloid transparent. Teknik celluloid ini merupakan teknik mendasar dalam pembuatan film versi animasi klasik. Cel animation teknik animasi inilah yang digunakan pada saat animasi pertama kali dikembangkan untuk media layar kaca (TV) dan layar perak (bioskop).
Pada film versi animasi“ Cinderella" 1950 dari segi kostum tidak bisa melihat setiap detail dari film versi animasi cel baru ditarik ke setiap frame . Pada bagian kostum pada film ini terlihat bahwa nilai kostum dalam menciptakan kepribadian tidak bisa dilebih-lebihkan. Selain daya tarik mata yang jelas dari warna dan desain yang dipakainya karakter membuatnya menjadi individu yang spesifik. Animasi 2D teknologi menggunakan peralatan yang sederhana dan proses penciptaan film versi animasi dengan media yang simple, sehingga dalam membuat animasi “Cinderella" secara 2D atau cel animation memerlukan waktu, tenaga, dan bahan yang lebih banyak dibandingkan dengan saat ini dengan menggunakan animasi komputer, karena dengan menggunakan animasi komputer waktu pembuataan juga lebih singkat dan tenaga yang diperlukan juga lebih sedikit karena tidak memerlukan tahap pembuatan manual dan pewarnaanya sendiri.

Di dalam cel animation, setiap frame merupakan hand drawn, dan membuat proses pembuatannya semakin panjang dan rumit. Oleh sebab itu, film versi animasi“ Cinderella" pada bagian kostum dan tata rias tidak terdapat detail ornamen karena akan menjadi rumit pada saat proses pembuatannya akan 
semakin panjang. Teknik ini hanya bertahan sampai ditemukannya Computer Animation Production System pada tahun 1990an. Perkembangan teknologi cel animation 2D dan saat ini sudah berkembang menjadi 3D menggunakan teknik digital.

\section{Kesimpulan}

Berdasarkan pada hasil penelitian pada bab ini dapat disimpulan sebagai berikut:

1. Film "Cinderella" versi live action tahun 2015 dengan film versi animasi tahun 1950 berhasil menghadirkan kostum dan tata rias dengan melakukan mix up pada setting tempat di Perancis pada abad ke 19 sekitar tahun 1937 pada masa Ratu Victoria menjabat di Inggris dengan menggunakan gaya Victorian seperti pada kostum Cinderella, Ibu Tiri, Anastasia, Drizella, dan Pangeran. Kostum dan tata rias juga tidak hanya menggunakan abad ke 19 dengan melakukan mix up dari periode-periode sebelumnya.

2. Kostum dan tata rias sesuai dengan 3 dimensi tokoh-tokoh pada kedua film pada tokoh Cinderella, Ibu Tiri, Anastasia, Drizella, dan Pangeran meliputi dimensi fisiologis dengan menggambarkan kondisi fisik tokoh seperti kesederhanaan, kemewahan, kecantikan, kegagahan, kerapihan, kewibawaan, dan daya 15rnam tokoh. Dimensi sosiologis menunjukan kelas 15rname ekonomi, kehidupan keluarga, kewarganegaraan, dan hobi pada tokoh. Dimensi psikologis menggambarkan perasaan sesuai warna pada kostum dan tata rias meliputi kepribadian, tempramen, cara tokoh menyikapi kehidupan seperti, kebaikan, keberanian, ketulusan, emosi, dan visi masingmasing tokoh pada kedua film tersebut. Kostum dan tata rias cara fashion bertolak pada tren setiap periode dalam berkomunikasi dan budaya, sebagai perlindungan, kesopanan, penyembunyian, daya tarik, ekspresi individualistik, nilai sosial atau status sosial, nilai ekonomi atau status ekonomi, dan pemaknaan internal maupun eksternal masing-masing tokoh. Kostum dan tata rias yang mencerminkan 3 dimensi tokoh sesuai dengan tahun pembuatannya. Pada tahun 2015 tokoh-tokoh diperkuat dengan detail ornamen dan asesoris yang digunakan untuk mendukung masingmasing tokoh. Sedangkan pada tahun 1950 dengan teknologi yang sangat sederhana pada saat itu kostum dan tata rias juga mencerminkan 3 dimensi tokoh.

3. Persamaan dan perbedaan kostum dan tata rias sudah sesuai dalam membangun 3 dimensi tokoh-tokoh 
diperoleh hasil dengan melihat dari jawaban dari kesimpulan pertama, kedua dan keempat.

4. Alasan terjadinya persamaan Film “Cinderella" versi tahun 2015 dengan film versi animasi tahun 1950 menggunakan setting tempat di Perancis pada abad ke 19 sekitar tahun 1937 pada masa Ratu Victoria menjabat di Inggris dengan menggunakan gaya Victorian seperti pada kostum Cinderella, Ibu Tiri, Anastasia, Drizella, dan Pangeran. Kostum juga tidak hanya menggunakan abad ke 19 dengan melakukan mix up dari periode-periode sebelumnya. Perbedaan terletak pada sifat medianya yang digunakan berbeda. Film animasi Cinderella pada tahun 1950 merupakan film traditional animation atau animasi dua dimensi masih menggunakan peralatan sederhana, dan media yang simple maka sangat sulit dalam menampilkan detail kostum. Pada film “Cinderella” 2015 dibuat sebuah film dengan tokoh film yang nyata diperankan oleh manusia dalam bentuk film live action, maka akan sangat mudah menampilkan detail kostum.

\section{Daftar Sumber Rujukan}

\section{A. Daftar Pustaka}

Arinkunto, Suharsimi. Prosedur Penelitian Suatu Pendekatan Praktik. Jakarta: Rineka Cipta, 2010.
Azwar, Saifuddin. Metode Penelitian. Yogyakarta: Pustaka Pelajar, 2004.

Burhan Bungin, H.M. Metodologi Penelitian Kuantitatif. Jakarta: Kencana Prenadamedia Group, 2005.

Bordwell, David, dan Kristin Thompson. Film art an introduction. London: McGraw-Hill Education, 2012.

Boggs, Joseph M. Cara Menilai Sebuah Film Terjemahan Asrul Sani dari The Art of Watching Film. Jakarta: Yayasan Citra, 1992.

Egri, Lagos. The Art of Dramatic Writing. New York: A touchstone, 1946. Landis, Deborah Nadoolman. Dressed a Century of Hollywood Costume Design. London: Colins, 2008.

Haryamawan, RMA. Dramaturgi. Bandung: PT Remaja Rosdakarya, 1998. Moelong, Lexy J. Metodologi Penelitian Kualitatif. Bandung: Rosdakarya Offset, 2007.

Nazir, Moh. Metode Penelitian. Bogor: Ghalia Indonesia, 2005.

Pandergast, Sara and Tom Pandergast. Fashion, Costume, and Culture: Clothing, Headwear, Body Decoration, and Footwear Through The Ages. Amerika: United States, 2004.

Paningkiran, Halim. Make-up Karakter Untuk Televisi dan Film. Jakarta: PT. Gramedia Pustaka Utama, 2013.

Prakosa, Gatot. Animasi Pengetahuan Dasar Film Animasi Indonesia. Fakultas Film dan Televisi-Institut Kesenian Jakarta: Yayasan Seni Visual Indonesia, 2010.

Prakosa, Gatot. Nganimasi Bersama Mas Be. Jakarta: Kompas Gramedia, 2012

Pratista, Himawan. Memahami Film. Yogyakarta: Homerian Pustaka, 2008.

Pratt, Luci dan Woolley, Linda. The Board of Trustees of The Victoria and Albert Museum 1999. London: V\&A Publications, 2000 
Reynolds, Helen terj. Sari, Selyana. A Fashionable History of Dresses and Skirts.

Jakarta: KPG (Kepustakaan Populer Gramedia), 2010.

Reynolds, Helen terj. Joubinaux, Julie. A Fashionable History of Coats and Trousers. Jakarta: KPG (Kepustakaan Populer Gramedia), 2010.

Reynolds, Helen terj. Joubinaux, Julie. A Fashionable of Underwear. Jakarta: KPG (Kepustakaan Populer Gramedia), 2010.

Reynolds, Helen terj. Joubinaux, Julie. A Fashionable of Hair and Hairstyles. Jakarta: KPG (Kepustakaan Populer Gramedia), 2010.

Reynolds, Helen terj. Joubinaux, Julie. A Fashionable of Jewellery and Accessories. Jakarta: KPG (Kepustakaan Populer Gramedia), 2010.

Sanyoto, S.E. Dasar-Dasar Tata Rupa dan Desain (Nirmana).Yogyakarta: CV Arti Bumi Intaran, 2005.

Satori, Djam'an, dan Aan Komariah. Metodologi Penelitian Kualitatif. Bandung: Alfabeta, 2013.

Strauss, Anselm, dan Juliet Corbin. DasarDasar Penelitian Kualitatif. Yogyakarta: Pustaka Pelajar, 2003

Sugiyono. Metode Penelitian Kuantitatif Kualitatif dan $R \& D$. Bandung: Alfabeta, 2014.

Suwartono. Dasar-Dasar Metodologi Penelitian. Yogyakarta: CV Andi Offset, 2014.

Thomas, Frank dan Ollie Johnston. The Illusion of Life Disney Animation. New York: Walt Disney Production, 1981.

Wibowo, Panji, Indrarto Totot, Devina Sofiyanti. Modul Penyutradaraan. Jakarta: Kementrian Pendidikan dan Kebudayaan Pusat Pengembangan
Perfilman, 2017. Yogyakarta: Institut Seni Indonesia Yogyakarta, 2017.

Zed, Mestika. Metode Penelitian Kepustakaan. Jakarta: Yayasan Obor Indonesia, 2004.

\section{Daftar Skripsi}

Galih, Gilang Dwi. Analisis Hubungan Perubahan Tata Artistik Dan Konten PadaProgram Talkshow "Hitam Putih" Trans 7 Periode 2010-2015. Institut Seni Indonesia Yogyakarta, 2017.

Galuh F, Nindya. Representasi Intelektualitas Anak Muda dalam Film Warkop DKI Setan Kredit dengan Analisis Semiotika Roland Barthes, 2017. Setiawan, Lalu Hendri Bagus. Komparasi Elemen Artistik Variety Show "Puteri Indonesia" Indosiar dan "Miss Indoneisa" Rcti Tahun Produksi 2016. Institut Seni Indonesia Yogyakarta, 2017.

Sintowoko, Dyah Ayu Wiwid. Kostum Dalam Membangun Karakter Tokoh Pada Film Soekarno. Institut Seni Indonesia Surakarta, 2014.

Yunastria, Ayu Paundra. Analisis Warna Artistik Sebagai Representasi Karakter Tokoh Keluarga Pada Sitkom Tetangga Masa Gitu? Season 3 di Net Tv. Institut Seni Indonesia Yogyakarta, 2017.

\section{Daftar Website}

Baca Terus. "10 Film Animasi Disney Terbaik Dari Kisah Dongeng" http://bacaterus.com/film-animasidisney-dongeng/ (diakses 01 Oktober 2017 13:27).

Harpersbazaa. "Sejarah Fashion Tahun 18501900"

http://www.harpersbazaar.co.id/articles/ $\mathrm{read} / 10 / 2016 / 2945 /$ Sejarah-Fashion-

Tahun-1850-1900 (diakses 15 Oktober 2017 13:00). 
Harpersbazaa. "10 Fakta Tentang Cinderella"

http://www.harpersbazaar.co.id/articles/ $\mathrm{read} / 3 / 2015 / 1427 / 10$-Fakta-Tentang-

Cinderella (diakses 15 Oktober 2017 13:30).

Desain Busana. "Sejarah Fashion Dunia" http://www.desainbusana.com/2012/08/ sejarah-fashion-dunia.html (diakses 15 Oktober 2017 14:30).

Uniknya Com. "5 Pakaian Bersejarah Perempuan Di Eropa" http://gayahidup.uniknya.com/2013/08/ 29/5-pakaian-bersejarah-perempuan-dieropa/ (diakses 15 Oktober 2017 15:30).

Kompasiana. "Sejarah Renaissance" https://www.kompasiana.com/wahyu_s etyaningsih/sejarahrenaissance_55007ea5813311971ffa78a d/ (diakses 15 Oktober 2017 15:45).

Boombastis. "5 Etika Bangsawan Zaman Ratu Victoria di Inggris Yang Bikin Hidup Makin Ribet" https://www.boombastis.com/etikabangsawan- inggris/55166 (diakses 15 Oktober 2017 16:40).

Merdeka.com. "Walt Disney Picture" https://profil.merdeka.com/mancanegar a/w/walt-disney-pictures/ (diakses 16 Oktober 2017 10:00).

Satujam.com. "Sejarah Disney" https://www.satujam.com/sejarahdisney/ (diakses 19 Oktober 2017 10:00).

Disney "Movie. "Cinderella" http://movies.disney.id/cinderella-1950 (diakses 19 Oktober 2017 10:00).

IMBD. "Sandy Powell" http://www.imdb.com/name/nm069430 9/ (diakses 19 Oktober 2017 12:00).

Victoria and Albert Museum. "Style Guide: Rococo" http://www.vam.ac.uk/content/articles/s /style-guide-rococo/ (diakses 24 Oktober 2017 10:00).

BBC. "History" http://www.bbc.co.uk/ history/british/victorians/ (diakses 24 Oktober 2017 13:00).

Bellatory. "Women's Fashions of the Victorian Era: From Hoop Skirts to Bustle - 1837 - 1901" https://bellatory.com/fashionindustry/Fashion-History- VictorianCostume-and-Design-Trends-18371900-With-Pictures (diakses 25 Oktober 2017 10:00).

AnimasiAnimasi. "Dasar Animasi" https://animasianimasi.weebly.com/cellanimation.html (diakses 21 Januari 2018 14:00).

Animasi Live Journal. "Animasi Tradisional" https://animasilivejournal.weebly.com/animasitradisional.html (diakses 21 Januari 2018 15:00).

Disney Style. "Cinderella Themed Tea and Showcase at London FashionWeek 2015"

https://www.youtube.com/watch?v=HB zTh1cAz8o (diakses 22 Januari 2018 14:00).

Laughingplace. "Cinderella Interview Sandy

Powell"' https://www.youtube.com/watch?v=2T L-m_R6Sps\&t=2s (diakses 22 Januari 2018 15:00). 